Chur, Basel, Neuchatel and Zurich during the month. The following have not been mentioned previously in the columns of NATURE : An earthquake on June I, registered at Chur at $09 \mathrm{~h} .04 \mathrm{~m} .11 .7 \mathrm{~s}$. U.T., which came apparently from an epicentre near the Presse Griechenland. The earthquake of June 20 which registered at Chur at $14 \mathrm{~h} .42 \mathrm{~m}$. $01 \cdot 8 \mathrm{~s}$. U.T. came probably from Trentino, Valle Judicaria, in Italy. The earthquake of June 25, which registered at Chur at $22 \mathrm{~h}$. $13 \mathrm{~m}$. $13 \cdot 9 \mathrm{~s}$. U.T., came apparantly from an epicentre at Mürtschenstock, Kt. Glarus, Switzerland, and was felt with intensity IV-V.

The earthquake of August 24 in Peru (Nature, September 5) was registered at Kew at $23 \mathrm{~h}$. $03 \mathrm{~m}$. $36 \mathrm{~s}$. U.T. and attained a maximum ground amplitude at Kew of $1,520 \mu$. The earthquake of August 27 in the Balkans (Nature, September 5) was also registered at Kew at $06 \mathrm{~h}$. $18 \mathrm{~m}$. 16s. U.T. and attained a maximum ground amplitude at Kew of $210 \mu$.

The United States Coast and Geodetic Survey in co-operation with Science Service and the Jesuit Seismological Association has determined the epicentres of several recent earthquakes near South America. These determinations have been based on instrumental reports from fifteen observatories. Altogether there are seven shocks, six being near latitude $0 \cdot 8^{\circ} \mathrm{N}$., longitude $80 \cdot 5^{\circ} \mathrm{W}$., which is just off the coast of northern Ecuador in South America. The dates of the shocks were all in July-4 (2), 5, 7, 8 and 12 . The seventh earthquake was on July 8 , and its opicentre was near latitude $25 \cdot 5^{\circ} \mathrm{S}$., longitude $79 \cdot 5^{\circ} \mathrm{W}$., which is in the bed of the Pacific Ocean off the coast of Chile, and north-east of the islands of San Felix and San Ambrosio.

\section{Data for Radio Engineers}

A small publication (Reference Data for Radio Engineers. Pp. 60. Standard Telephones and Cables, Ltd., 63 Aldwych, W.C.2. 2s.) should find a ready appeal to all radio engineers, whether they are en. gaged in replacing a small fixed resistor in a wireless receiver or a piece of laboratory apparatus, or working on the design of a world-wide radio telephone service. The data included in this booklet have been selected as a result of the experience of engineers engaged in the development of radio communication systerns during the past twenty years. A very wide field is covered including electrical and mechanical constants, properties of materials, circuit theorems, impedance operators, abacs and other data of everyday utility to those conducting design and development work. A noteworthy inclusion is that of wave propagation curves summarizing the best technical knowledge available at an international conference held in 1938. The above material is supplemented by a generous amount of mathematical formula, and the usual tabulated quantities up to and including tables of Bessel functions, the need for which has grown so rapidly of recent years in connexion with phase- and frequency-modulation systems. Since the effectiveness of any communication link, land-line or radio is nowadays expressed in terms of the ratio of the wanted signal to the noise-level, it is only natural to find a fow pages devoted to noise determination and measurement, and charts showing the relationship between the European and American units in the standardization of noise measurement. The reference book is a commendable effort in a comparatively new field.

\section{Announcements}

Sir Robert RENwick has been appointed to the newly created post of Controller of Communications Equipment in the Ministry of Aircraft Production, and will become a member of the Aircraft Supply Council. He will be assisted by Sir Robert Watson Watt, as vice-controller. Sir Robert Renwick has also been appointed controller of communications in the Air Ministry, where Sir Robert Watson Watt will continue to hold the appointment of scientific adviser on telecommunications. These arrangements will ensure still closer co-ordination between the two departments in this important field.

The following appointments in the Colonial Service have recently been made : P. H. Richards, agricultural officer, Nigeria ; B. J. Silk, agricultural officer, Gold Coast; M. P. Ford, veterinary olficer, Kenya; A. E. (․ Markham, veterinary officer, Kenya ; C. O. Oates (agricultural oficer), senior agricultural officer, Kenya; K. Wallis (government analyst, British (Guiana), government chemist, Uganda.

Arising out of a recommendation made to the Council of the British Association at the conclusion of the Conference on European Agriculture, a committee has been appointed, under the chairmanship of Sir John Russell, to collaborate with the Allied Technical Advisory Committee on scientific problems connected with the post war reconstruction of agriculture in the devastated and oppressed areas of Europe. The Council of the Association has also appointed a committee, under the cheirmanship of Dr. Dudley Stamp, with the view of strengthening the applications of science (for example, geology, geography, ecological botany and zoology, soil science, agricultural economics, and forestry) to rural planning in particular.

The first lecture in the autumn programme of the thirtieth annual series of Chadwick Public Lectures will be given at the Royal Society of Tropical Medicine, 26 Portland Place, London, W.1, on October 6, at 2.30, when Sir Leonard Hill will lecture on "The Inter-Relation of Clothing and Shortage of Fuel in Matters of Health". Sir William J. Collins, chairman of the Chadwick Trustees, will preside, and shortly before the lecture (at 2.15 p.m.) will present the Chadwick Medal and Prize to Mr. Wilfred Glyndon May of University College, London. Admission to all the lectures is free and tickets are not required.

The Medical Research Council invites applications from modically qualified women for a studentship for training in methods of experimental psychology; preference will be given to candidates who have had some special training in physiology or neurology, or who have already had some experience in the use of research methods. The studentship will be tenable for six months, during which the holder will receive training under the direction of Prof. F. C. Bartlett at Cambridge. Payment will be at the rate of $£ 350$ per annum and the student will be expected to give her whole time to the work. Further information can be obtained from the Secretary, Medical Research Council, c/o London School of Hygiene, Keppel Street, London, W.C.1, to whom application should be made by October 5 . 